\title{
PENGELOLAAN PENCAIRAN BOP MELALUI PENDATAAN TPQ PADA EMIS DI KANTOR KEMENTERIAN AGAMA KOTA MOJOKERTO
}

\author{
Dyana Maftuhatu Rosyidah, Hamid Muzakki, Innanda Oqta Putri \\ Wulandary, Mukhlishah \\ UIN Sunan Ampel, Surabaya - Indonesia | dyanamaftuhaturosyidah7@gmail.com
}

\begin{abstract}
Abstrak: Pelaksanaan penelitian ini bertujuan untuk mengetahui proses pengelolaan pencairan biaya operasional (BOP) melalui pendataan Taman Pendidikan Al-Qur'an (TPQ) Pada Education Manajemen Information System (EMIS) di Kantor Kementerian Agama Kota Mojokerto. Penelitian ini dilaksanakan dengan menggunakan metode deskriptif kualitatif. Subyek dari penelitian ini adalah bagian administrasi dibidang Pendidikan Agama dan Keagamaan Islam (PAKIS) yang mengurusi EMIS PONTREN, Setelah dilakukan penelitian melalui teknik pengumpulan data menggunakan wawancara, observasi dan dokumentasi, dapat disimpulkan bahwa pendataan berjalan dengan kurang maksimal. Terdapat beberapa kendala yang dialami oleh bagian administrasi PAKIS, kendala tersebut berasal dari Sumberdaya Manusia, Jaringan dan server yang kurang stabil, serta menu dari aplikasi EMIS yang kurang lengkap, semua kendala tersebut perlu diatasi dengan pembuatan link khusus atau group Whatsapp pengisian data TPQ oleh pihak administrasi PAKIS Kementerian Agama Kota Mojokerto, dengan adanya link khusus atau group Whatsapp tersebut, maka pengisian data dapat berjalan dengan lebih efektif dan efisien, untuk selanjutnya data tersebut diolah dalam aplikasi EMIS dan digunakan untuk syarat pencaitan dana BOP bagi TPQ di wilayah Kota Mojokerto.
\end{abstract}

Keywords: EMIS, BOP, TPQ, Pengelolaa

\section{Pemdahuluan}

Dalam era global, perkembangan ilmu pengetahuan dan teknologi yang semakin pesat menjadi tuntutan dalam memberikan informasi yang cepat, tepat dan akurat.1 Perkembangan teknologi informasi dapat meningkatkan kinerja dan memungkinkan berbagai 
kegiatan dapat dilaksanakan dengan cepat, tepat, dan akurat, sehingga akhirnya produktivitas akan meningkat.2 Perkembangan teknologi informasi berdampak pada bermunculnya berbagai jenis kegiatan yang berbasis pada teknologi, seperti e-government, ecommerce, e-education, e- medicine, e-laboratory, dan lainnya, yang semuanya itu berbasis elektronik.

Kebutuhan akan teknologi yang menekankan pada efisiensi dan efektifitas tentu menjadi kebutuhan setiap instansi untuk meningkatkan kualitas di intansi atau organisasi.3 Seperti di perusahaan, rumah sakit, instansi pemerintah dan tak terkecuali di lembaga pendidikan islam.

Kementerian Agama telah menggunakan Sistem Informasi Manajemen (SIM) pendidikan yang bernama Education Management Informartion System (EMIS) yang diharapkan menjadi solusi untuk kemajuan lembaga-lembaga pendidikan yang berada di bawah naungan Kementerian Agama.4 Dengan adanya EMIS, semua data lembaga, siswa, guru dan lain-lain terkumpul menjadi satu. Tentunya dalam pengumpulan data ini harus ada pengelolaan yang baik dan tepat. Namun, dalam pelaksanaannya di Kota Mojokerto masih banyak kendala saat pendataan lembaga pendidikan islam seperti TPQ. Seperti ada kesalahan dan kekurangan syarat untuk pengajuan proposal izin operasional lembaga tapi mereka pihak lembaga TPQ menolak untuk merevisinya. Hal ini seharusnya tidak terjadi jika petugas EMIS bisa mengelola dan menegaskan kepada lembaga pendidikan islam TPQ agar bisa membuat proposal yan baik dan mau merevisi jika ada kesalahan.

Penelitian ini berusaha menganalisis Pengelolaan Pencairan BOP Melalui Pendataan TPQ Pada EMIS Di Kantor Kementerian Agama Kota Mojokerto. Masalah yang ingin dijawab yaitu bagaimana pengelolaan pencairan bop dan pendataan lembaga TPQ pada EMIS di Kantor Kementerian Agama Kota Mojokerto.

\section{Pengelolaan}

Menurut KBBI, pengelolaan artinya proses melakukan kegiatan tertentu dengan menggerakkan tenaga orang lain.5 Menurut Purwanto, pengelolaan adalah kegiatan untuk mencapai sasaran- 
sasaran tertentu dengan menggunakan orang-orang sebagai pelaksananya. Menurut Sondang P. Siagian, pengelolaan adalah keterampilan untuk mencapai suatu hasil tertentu dengan menggunakan tenaga dan bantuan orang lain. menurut George R. Terry, pengelolaan adalah pemanfaatan sumber daya manusia ataupun sumber daya lainnya yang dapat diwujudkan dalam kegiatan perencanaan, pengorganisasian, pengarahan dan pengawasan untuk mencapai suatu tujuan tertentu. Menurut Harold Koontz, pengelolaan adalah usaha untuk mencapai tujuan tertentu dengan menggunakan tenaga orang lain. Menurut Andrew F. Sikul, pengelolaan adalah serangkaian aktivitas-aktivitas koordinasi yang mencakup perencanaan, pengorganisasian, pengarahan, pengendalian, penempatan serta pengambilan keputusan untuk menghasilkan suatu produk dan jasa yang efektif dan efesien.6 Pengelolaan adalah suatu proses kegiatan tertentu yang menggunakan tenaga manusia dan memberikan pengawasan pada semua hal yang terlibat pada pelaksanaan kebijaksanaan untuk mencapai tujuan tertentu.7 Jadi pengelolaan adalah suatu kegiatan yang, menggunakan tenaga manusia untuk mencapai tujuan tertentu.

\section{Sistem Informasi Manajemen (SIM)}

Sistem Informasi Manajemen adalah bagian perencanaan dari pengendalian internal suatu bisnis yang meliputi pemanfaatan manusia, dokumen, teknologi, dan prosedur oleh akuntansi manajemen untuk memecahkan masalah bisnis seperti biaya produk, layanan, atau suatu strategi bisnis. Sistem informasi manajemen dibedakan dengan sistem informasi biasa karena SIM digunakan untuk menganalisis sistem informasi lain yang diterapkan pada aktivitas operasional organisasi. Secara akademis, istilah ini umumnya digunakan untuk merujuk pada kelompok metode manajemen informasi yang bertalian dengan otomasi atau dukungan terhadap pengambilan keputusan manusia, misalnya sistem pendukung keputusan, sistem pakar, dan sistem informasi eksekutif. Tujuan dari sistem informasi manajemen yaitu memecahkan beragam masalah yang terdapat dalam bisnis meliputi layanan, biaya produk, serta strategi bisnis. Keseluruhan sistem 
yang digunakan dalam rangka menganalisis sistem informasi yang lain pada penerapan aktivitas operasional dalam organisasi.8

Sistem informasi manajemen menurut Suyadi Prawisentono adalah sebagai suatu infrastruktur yang memfasilitasi pihak manajemen yang memerlukan informasi untuk pengambilan keputusan organisasi dengan basis Total Quality Management dengan tujuan memenangkan persaingan melalui pembuatan produk yang berkesesuaian mutu dengan konsumen. Menurut Vincent, system informasi manajemen adalah suatu jaringan prosedur pengolahan data yang dikembangan dalam suatu organisasi dan disatukan bila dipandang perlu dengan maksud memberikan data kepada pihak manajemen setiap waktu diperlukan, baik data yang bersifat intern maupun bersifat ekstern untuk dasar pengambilan keputusan dalam rangka tujuan organisasi. Menurut Water J Kennevan, sistem informasi manajemen adalah suatu cara yang terorganisasi dalam penyediaan informasi masa lalu, informasi masa kini, dan informasi yang diproyeksikan pada masa dating yang berkaitan dengan operasi internal dan eksternal. 9Sistem Informasi Manajemen (SIM) berbasis web sangat bermanfaat untk mendukung proses manajemen pendidikan. Pemanfaatan teknologi informasi manajemen khususnya dalam bidang pendidikan sudah sangat diperlukan dalam pengelolaan data sekolah, salah satunya dalam pengelolaan data siswa. Menurut Sabandi dan Vindi, Sistem Informasi Manajemen adalah sebuah metode yang digunakan oleh pemakai informasi untuk mengelola data, baik itu data siswa maupun data guru yang akan menjadi sebuah informasi yang kemudian hasil dari informasi tersebut dijadikan sebagai bahan pertimbangan dalam sebuah proses pengambilan keputusan.10

\section{Education Management Information System (EMIS)}

Education Management Information System (EMIS) adalah sekumpulan informasi dokumentasi yang terorganisasi dalam melaksanakan pengumpulan, penyimpanan, pengolahan, analisis, dan penyebaran informasi yang digunakan untuk manajemen dan Education Management Information System (EMIS) adalah sekumpulan informasi dokumentasi yang terorganisasi dalam 
melaksanakan pengumpulan, penyimpanan, pengolahan, analisis, dan penyebaran informasi yang digunakan untuk manajemen dan perencanaan pendidikan. Sistem EMIS digunakan untuk mengatur data dan informasi pendidikan dalam jumlah besar yang dapat dibaca, diambil kembali, diproses, dianalisis, dan disajikan dan disebarkan.11

Penggunaan EMIS dalam sisten informasi manajemen pendidikan di lingkungan Kementerian Agama memiliki tujuan sebagai berikut, (1) Memperkuat kemampuan untuk mengatur, merencanakan, mengawasi alur informasi antar instansi yang saling berhubungan,

(2) Memadukan seluruh informasi yang berhubungan dengan manajemen kegiatan pendidikan dan menyajikannya secara ringkas dan menyeluruh, (3) Memperbaiki kapasitas pengolahan, penyimpanan dan analis data dalam menyediakan informasi yang terpercaya dan tepat waktu bagi perencana, pemimpin, dan penanggung jawab bidang pendidikan, (4) Mengkoordinasikan proses pengumpulan, penyimpanan, pengolahan, analisis dan penyebaran informasi dalam manajemen pendidikan, (5) Memudahlan dan meningkatkan penggunaan informasi yang sesuai oleh berbagai instansi dan perorangan pada semua jenjang agar perencanaan, pelaksanaan, dan manajemen pendidikan dapat lebih efektif, (6) Menyederhanakan alur informasi dalam pengambilan keputusan dengan menghapus proses duplikasi dan perbedaan pengisian informasi, (7) Mengaitkan berbagai system informasi yang ada, (8) Memadukan berbagai sumber informasi kuantitatif dan kualitatif dalam suatu system dan (9) Memperbaiki proses pengumpulan, penyebaran, dan penggunaan informasi manajemen pendidikan dalam menanggapi perubahan kebutuhan informasi.12

\section{Bantuan Operasional Pendidikan (BOP)}

Pondok Pesantren sebagai bagian elemen lembaga masyarakat yang salah satu perannya melaksanakan pendidikan agama Islam telah memberikan kontribusi besar pembentukan karakter bangsa. Dengan kemandirian yang telah dibuktikan selama ini, pesantren dapat menunjukkan diri sebagai lembaga independent yang bisa menjaga irama kehidupan yang harmonis di tengah-tengah 
kemajemukan warga negara Indonesia untuk memperkokoh NKRI. Dengan kontribusi yang ditunjukkan pesantren tersebut, pemerintah hadir melalui program Bantuan Operasional Pendidikan Pondok Pesantren untuk memberikan "stimulan", baik melalui program peningkatan mutu akademik, peningkatan kualitas dan kompetensi ustadz / santri, maupun mutu di bidang sarana dan prasarana. Agar pengalokasian dan pengelolaan Bantuan Operasional. Pendidikan Pondok Pesantren dapat dilaksanakan secara tertib, efisien, ekonomis, efektif, transparan dan bertanggung jawab dengan memperhatikan rasa keadilan dan kepatutan, maka dipandang perlu untuk mengatur ketentuan mengenai Petunjuk Teknis Bantuan Operasional Pendidikan Pondok Pesantren.

Tujuan BOP Pondok Pesantren adalah untuk meringankan biaya operasional pendidikan pada pondok pesantren, untuk mengurangi angka putus sekolah bagi santri yang kurang mampu, untuk memberikan layanan pendidikan yang terjangkau dan bermutu, ntuk mewujudkan keberpihakan pemerintah bagi santri dengan membantu tagihan biaya sekolah.13 Bantuan Operasional Pendidikan Pondok Pesantren adalah Bantuan pemerintah yang diberikan kepada pondok pesantren untuk biaya operasional pendidikan. Pengguna Anggaran yang selanjutnya disingkat PA adalah Menteri Agama sebagai pejabat pemegang kewenangan penggunaan anggaran Kementerian Agama. Kuasa Pengguna Anggaran yang selanjutnya disingkat KPA adalah Pejabat yang memperoleh kuasa dari PA untuk melaksanakan sebagian kewenangan dan tanggungjawab penggunaan anggaran pada Kementerian Agama. Pejabat Pembuat Komitmen yang selanjutnya disingkat PPK adalah pejabat yang melakukan tindakan yang mengakibatkan pengeluaran belanja negara. Direktorat Pendidikan Diniyah dan Pondok Pesantren adalah Direktorat pada Direktorat Jenderal Pendidikan Islam Kementerian Agama RI yang melaksanakan perumusan dan pelaksanaan kebijakan, standardisasi, bimbingan teknis serta evaluasi di bidang pendidikan diniyah dan pondok pesantren. Bidang Pendidikan Diniyah dan Pondok Pesantren/TOS adalah bidang pada Kantor Wilayah 
Kementerian Agama Provinsi yang melaksanakan pelayanan, bimbingan, pembinaan dan pengelolaan sistem informasi di bidang pendidikan diniyah dan pondok pesantren. Seksi Pendidikan Diniyah dan Pondok Pesantren/TOS adalah seksi pada Kantor Kementerian Agama Kab/Kota yang melaksanakan pelayanan, bimbingan teknis, pembinaan serta pengelolaan data dan informasi di bidang pendidikan diniyah dan pondok pesantren. Daftar Isian Pelaksanaan Anggaran adalah Dokumen Pelaksanaan Anggaran yang digunakan sebagai acuan Pengguna Anggaran dalam melaksanakan kegiatan pemerintahan sebagai pelaksanaan anggaran pendapatan dan belanja Negara. Aparat Pengawas Intern Pemerintah adalah pengawas internal pada institusi lain yang selanjutnya disebut APIP yang melakukan pengawasan melalui audit, review, evaluasi, pemantauan dan kegiatan pengawasan lain terhadap penyelenggaraan tugas dan fungsi organisasi. Swakelola adalah Pengadaan Barang/Jasa dimana pekerjaannya direncanakan, dikerjakan dan/atau diawasi sendiri oleh $\mathrm{K} / \mathrm{L} / \mathrm{D} / \mathrm{I}$ sebagai penanggung jawab anggaran, instansi pemerintah lain dan/atau kelompok masyarakat. Kelompok Masyarakat (POKMAS) adalah sekumpulan orang yang dibentuk oleh masyarakat untuk mewujudkan kesamaan maksud dan tujuan tertentu di bidang sosial, keagamaan, pendidikan agama dan pendidikan keagamaan, dan kemanusiaan yang tidak membagikan keuntungan kepada anggotanya. Surat Perjanjian yang selanjutnya disebut Kontrak adalah perjanjian tertulis antara PPK dengan Kelompok masyarakat. Pakta Integritas adalah surat pernyataan kesanggupan melaksanakan BOP Pondok Pesantren secara akuntabel, efektif, efisien dan bebas dari korupsi. Rencana Anggaran Biaya (RAB) adalah perhitungan perkiraan biaya pekerjaan yang disusun oleh Tim Perencana, dikalkulasikan secara keahlian berdasarkan data yang dapat dipertanggungjawabkan serta digunakan oleh Tim Pelaksana untuk melaksanakan BOP Pondok Pesantren. Jadwal Pelaksanaan adalah jadwal yang menunjukkan kebutuhan waktu yang diperlukan untuk menyelesaikan pekerjaan pembangunan, terdiri atas tahap pelaksanaan yang disusun secara logis, realistik dan dapat dilaksanakan. 14 
Pemberi Bop Pondok Pesantren Tahun Anggaran 2019 adalah Direktorat Jenderal Pendidikan Islam/Kantor Wilayah Kemenag Propinsi/Kantor Kemenag Kab/Kota.

\section{Taman Pendidikan Al-Qur'an (TPQ)}

Taman Pendidikan Al-Qur'an (TPQ) adalah lembaga atau kelompok masyarakat yang menyelenggarakan pendidikan nonformal jenis keagamaan islam yang bertujuan untuk memberikan pengajaran membaca Al-Qur'an sejak usia dini, serta memahami dasar-dasar dinul islam pada anak usia Taman KanakKanak, Sekolah Dasar, atau Madrasah Ibtidaiyah (SD/MI) atau bahkan SMP/MTS. TPQ setara dengan RA dan taman kanak-kanak (TK), dimana kurikulumnya ditekankan pada pemberian dasardasar bagaimana cara membaca Al-Qur'an serta membantu pembelajaran agama untuk pertumbuhan dan perkembangan rohani anak agar memiliki kesiapan dalam memasuki pendidikan lebih lanjut. 15

Dasar hukum TPQ ini ada di Peraturan Pemerintah No. 55 Tahun 2007 pasal 24 ayat 2 tentang Pendidikan Agama dan Pendidikan Keagamaan menyatakan bahwa pendidikan Al- Qur'an terdiri dari Taman Kanak-Kanak Al-Qur'an (TKA/TKQ), Taman Pendidikan Al- Qur'an (TPA/TPQ), Ta'limul Qur'an lil Aulad (TQA), dan bentuk lainnya yang sejenis.16

\section{Metodologi}

Penelitian ini menggunakan jenis penelitian kualitatif. Penelitian klualitatif merupakan penelitian yang menganut pada aliran fenomenologis, yang menitikberatkan kegiatan penelitian ilmiahnya dengan penguraian dan pemahaman terkait gejala-gejala sosial yang sedang diamati. Penelitian dilakukan pada tanggal 15-16 Oktober 2020 dan lokasi yang kami gunakan sebagai tempat penelitian adalah Seksi Pendidikan Agama dan Keagamaan Islam pada Kantor Kementrian Agama Kota Mojokerto.

Sumber data dalam penelitian kualitatif dapat berupa manusia, peristiwa, dan tingkah laku, dokumen dan arsip, serta beberapa benda lain. Sumber data dalam penelitian ini adalah informan, karena informan merupakan pelaksana dalam kegiatan yang 
hendak kami teliti. Informan dalam penelitian ini adalah pegawai pada seksi pendidikan agama dan keagamaan islam.

Instrument penelitian dalam penelitian kualitatif adalah peneliti itu sendiri. Oleh karena itu sebagai instrument, peneliti juga harus di validasi seberapa jauh peneliti kualitatif melakukan penelitian yang selanjutnya akan terjun ke lapangan. Jadi instrument kunci dalam penelitian kualitatif adalah peneliti itu sendiri. Teknik pengumpulan data merupakan langkah yang strategis dalam penelitian, karena memiliki tujuan untuk mendapatkan data. Tanpa kita mengetahui teknik pengumpulan data, peneliti tidak akan mendapatkan data sesuai dengan standar yang telah ditetapkan. Teknik pengumpulan data yang digunakan adalah teknik wawancara, dokumentasi, dan observasi.

Wawancara merupakan tanya jawab antara dua orang atau lebih secara langsung dengan maksud tertentu. Disini peneliti akan mewawancarai salah satu pegawai yang bekerja di Seksi Pendidikan Agama dan Keagamaan Islam. Melalui metode observasi atau pengamatan maka peneliti akan melihat secara langsung perilaku dan kejadian yang sebenarnya terjadi di lokasi tempat peneliti melakukan penelitian. Pengamatan atau observasi dilakukan untuk meperoleh informasi tentang aplikasi Education Managemen Information System (EMIS) yang dikelola oleh Seksi Pendidikan Agama dan Keagamaan Islam.

Teknik pengumpulan data dengan menggunakan metode dokumentasi merupakan pengambilan data yang diperoleh melalui dokumen-dokumen. Dokumentasi diperlukan untuk mengumpulkan data berupa struktur organisasi, foto-foto, serta dokumen lain yang berhubungan dengan EMIS di Seksi Pendidikan Agama dan Keagamaan Islam.

Analisis data merupakan sebuah proses untuk mencari dan menyusun secara sistematis data yang diperoleh dari hasil pengumpulan data, sehingga data tersebut dapat dengan mudah dipahami, serta semuannya dapat diinformasikan kepada orang lain. Teknik analis data yang dilakukan oleh peneliti adalah meliputi tahapan:

Pengumpulan data (data collection) 
Data-data yang diperoleh dari administrator EMIS di Kementerian Agama Kota Mojokerto berasal dari narasumber dengan tidak ada penambahan dari peneliti. Pencatatan dilakukan berdasarkan hasil wawancara. Dibuat dengan bentuk catatan kecil dan rekaman suara. Catatan dan rekaman tersebut kemudian didiskripsikan menjadi sebuah narasi deskriptif atas fenomena yang terjadi dilapangan.

\section{Reduksi Data (Reduction)}

Reduksi data adalah proses pemilihan, pemusatan perhatian, pada penyederhanaan, pengabsrakkan dan transformasi data kasar yang muncul dari catatan lapangan. Reduksi data merupakan wujud analisis yang menajamkan, mengklafikasikan, mengarahkan, membuang data yang tidak berkaitan dengan aktivitas EMIS di Kementerian Agama Kota Mojokerto.

\section{Penyajian Data (display)}

Langkah sesudah mereduksi data adalah penyajian data. Teknik penyajian data dalam kualitatif adalah berupa uraian, bagan, hubungan antar katagori, dan sejenisnya. Pada tahap ini disajikan data hasil temuan dilapangan dalam bentuk teks naratif, yaitu uraian verbal tentang perencanaan, pelaksanaan, hingga evaluasi EMIS di Kementerian Agama Kota Mojokerto.

Sebelum menggunakan emis perlu adanya persiapan pendaftaran lembaga ke kemenag kota mojokerto. Dalam pendaftaran lembaga perlu mempersiapkan persyaratan persyaratan yang harus di lengkapi mulai surat izin dari kelurahan surat rekomendasi dari KUA sampai SK dari Kemenkumham yang harus di siapkan lembaga. Setelah lembaga terdaftarb kemenag yang sudah di verivikasi lembaga bisa mengajukan untuk mendaftar ke dalam aplikasi emis. Adapun cakupan dari emis mencakup lembaga madarasah Diniyah, pondok pesantren, TPQ dll. Persyaratan dalam mendaftar emis adalah email lembaga, no hanpone dan surat tugas/SK operator madarasah.

EMIS di gunakan sebagai data base yang sebagai acuan kemenag. EMIS di gunakan sebagai data primer yang di gunakan sebagai acuan oleh kemenag dalam memberi pelayanan oleh kemenag, untuk mendapat bantuan dari kemenag, perhitungan 
siswa dalam pencairan dana bos, dan data santri/siswa yang di ikutkan dalam ujian nasional. Jadi jelas di sini bahwa emis adalah sistem informasi manajemen yang di gunakan kemenag dalam mengelola memberi layanan dan membantu lembaga dalam pencairan dana untuk operasional lembaga pendidikan yang di naungi kemenag baik formal maupun non formal.

Dari hasil wawancara banyak evaluasi yang kami dapatkan dalam pengoperasian emis ini. Misalnya kurang pahamnya operator madarasah mengenai sistem kerja emis. Kiranya tenaga ahli dalam bidang IT di sebuah lembaga karena banyaknya lembaga non formal yang ada di bawah naungan kemenag banyak juga lembaga yang tidak mempunyai operator khusus yang menangani Emis ini. Banyak data yang rancu sehingga membuat operator dari kemenag bingung sehingga banyak data yang di rekap ulang oleh operator kemenag yang seharusnya tidak mengerjakan entry data siswa/santri. Sering lupanya password dan kata sandi yang mengakibatkan tidak bisanya login pada aplikasi EMIS.

Perlu adanya sebuah pelatihan dan pengembangan bagi para operator lembaga agar operator yang ada di dalam lembaga mengetahui cara kerja dan tidak menambah beban operator kemenag kota Mojokerto. Perlu adanya operator yang pasti dalam pengerjaan emis lemabaga pendidikan.

\section{Penarikan Kesimpulan dan Verifikasi}

Dalam analisis data kualitatif menyimpulkan dan kesimpulan verifikasi. Dengan demikian kesimpulan dalam penelitian kualitatif mungkin dapat menjawab rumusan masalah yang dirumuskan pada awal penelitian. Namun juga terdapat kemungkinan tidak

\section{Hasil dan Pembahasan}

\section{Proses pencairan BOP TPQ}

Berdasarkan SK Direktur Jenderal Pendidikan Islam Kementerian Agama No.5164 Tahun Anggaran 2020, Persyaratan penerima Bantuan Operasional Pendidikan Al-Qurán diantaranya sebagai berikut:

- Membawa KTP (Asli dan foto copy)

- Membawa SK Pengurus Lembaga (foto copy) 
- Nomor Statistik/Izin Operasional Lembaga (foto copy)

- Membawa Materai 6000 (3 lembar)

- Membawa Stempel Lembaga

- Membawa Lampiran Surat Pemberitahuan17

Pada syarat ketiga dijelaskan bahwasanya penerima bantuan harus terdaftar pada Kantor Kementerian Agama Kab./Kota setempat dibuktikan dengan Izin Operasional Pendidikan AlQurán, bagi yayasan/TPQ yang belum memiliki izin operasional diwajibkan terlebih dahulu mengurus izin operasional TPQ dikantor Kementerian Agama Kabupaten/Kota setempat. Proses dari pelaksanaan pembuatan izin operasional ini memerlukan beberapa data yang harus dipenuhi, yaitu:

- Surat Permohonan Izin Operasional TPQ

- Surat Pernyataan Pemohon Izin Operasional

- Formulir Permohonan Izin Operasional TPQ

- Rekomendasi KUA tentang Permohonan Izin Operasional TPQ

- Keterangan Domisili dari Desa/Kelurahan

- Fotocopy Akta Notaris Yayasan/TPQ

- Fotocopy NPWP

- Fotocopy bukti kepemilikan tanah milik atau wakaf yang sah atas nama yayasan/TPQ

- Fotocopy KEMENHUMKAM

- Bukti foto KBM (Per Ustadz/15 Santri) Setelah semua syarat pengajuan izin operasional diatas terpenuhi, prosedur selanjunya adalah:

- Permohonan tertulis ditujukan kepada Kepala Kantor Kementerian Agama Kabupaten/Kota Setempat. Dilampirkan proposal pendirian, dilengkapi susunan pengurus, daftar nama santri/murid, daftar nama guru/ustadz, surat pernyataan, keterangan domisili, foto-foto kegiatan dan rekomendasi (Dijilid Rapi memakai sampul warna kuning)

- Kepala Seksi Pendidikan Diniyah dan Pondok Pesantren memeriksa proposal dan kelengkapannya serta melakukan monitoring kepada TPA/TPQ bersangkutan, selanjutnya akan menertbitkan sebagai berikut : 
- SK Pendirian/Izin Operasional TPA/TPQ oleh Kepala Kantor Kementerian Agama Kabupaten/Kota Setempat

- Pemberian nomor Statistik dalam bentuk piagam sebagai bukti TPA/TPQ telah terdaftar oleh Kepala Seksi PD. Pontren atau Kepala Kantor Kementerian Agama Kabupaten/Kota Setempat18

Ketika semua proses diatas telah dilaksanakan, maka pihak TPQ akan menerima Nomor Statistik dari Kementerian Agama Kabupaten/Kota sebagai tanda bukti keberadaan dan keaktifan,TPQ tersebut.

Untuk selanjutnya, setelah semua syarat administrasi permohonan pencairan BOP telah terpenuhi, maka pihak TPQ mengajukan semua syarat tersebut kepada pihak penyelenggara bantuan, pecairan BOP akan dikirim secara langsung kepada rekening yayasan/TPQ, bukan kepada rekening perorangan, setelah dana BOP cair, tentunya pihak yayasan/TPQ harus tetap membuat laporan pertangggungjawaban hasil pelaksanaan program BOP Yayasan/TPQ kepada Direktorat Pendidikan Diniyah dan Pondok Pesantren/Kanwil Kementerian Agama/Kantor Kementerian Agama Kabupaten/ Kota.

Kendala yang terjadi dalam proses pengolahan data dan pencairan BOP di Kementerian Agama Kota Mojokerto

Berdasarkan wawancara yang kami lakukan bersama staff Administrasi di Kantor Kementerian Agama Kota Mojokerto bagian Pontren yang mengurusi BOP TPQ yakni ibu Ika, terdapat beberapa kendala yang terjadi dilapangan, yaitu:

\section{Sumberdaya manusia,}

Sumberdaya manusia merupakan kendala terbesar yang ada dilapangan, sumberdaya yang dimaksud adalah para guru dari TPQ sendiri, dikarenakan TPQ ini merupakan lembaga pendidikan nonformal yang beroperasi hanya 1-2 jam perharinya,sehingga tidak adanya tenaga Tata Usaha (TU) khusus untuk mengurusi Administrasi TPQ, maka beberapa guru TPQ merangkap menjadi TU, belum lagi terdapat beberapa guru yang telah berusia lanjut, sehingga kurang begitu mengerti tentang teknologi, hal inilah yang membuat pelaksaan proses pemenuhan persyaratan ijin operasional 
menjadi terhambat dan berjalan lama, karena dari pihak sumberdayanya sendiri kurang maksimal. Tarhambatnya proses perijinan operasional ini, juga berdampak pada cairnya BOP, seperti yang telah diketahui bahwasanya salah satu syarat dari pencairan BOP TPQ adalah surat rekomendasi dari Kementerian Agama Kabupaten/Kota setempat. Setelah semua syarat data terpenuhi, lalu akan diproses dan diinput kedalam aplikasi EMIS, setelah semuanya selesai, barulah TPQ tersebut mendapatkan surat rekomendasi dari Kementerian Agama Kota Mojokerto.

\section{Jaringan dan Kondisi Server}

Penginputan data online menggunakan aplikasi EMIS tentunya mengharuskan pengguna untuk menggunakan internet untuk mengaksesnya, terkadang jaringan internet yang kurang baik membuat pengguna tidak dapat mengakses aplikasi EMIS, server error juga menjadi salah satu penghambat dalam proses pengolahan data, terutama disaat jam sibuk, karena satu Indonesia mengaksesnya secara bersamaan terkadang menyebabkan server down dan pengguna sulit untuk mengaksesnya, sehingga pengguna memilih untuk mengakses diwaktu-waktu luang, seperti waktu istirahat siang yakni sekitar jam 12.00 sampai jam 14.00 karena ketika sore hari atau pun malam hari, sehingga para petugas administrasi lembur.

\section{Aplikasi EMIS khusus Kementerian Agama kurang rinci}

Terdapat jenis EMIS yang hanya dapat diakses oleh pihak Kementerian Agama yang bernama e-monitor EMIS, aplikasi ini sedikit berbeda dengan EMIS pada umumnya, EMIS ini berisikan data secara global, sebagai contoh dalam e-monitor EMIS ini, berisikan data seluruh TPQ yang ada di wilayah Kota Mojokerto, namun ketika pihak Administor Kementerian Agama ingin mengakses data seluruh nama santri di TPQ X, data tersebut tidak dapat muncul, karena tidak ada dalam system, jadi jika ingin mengakses data seluruh nama santri di TPQ X, pihak Administrator Kementerian Agama harus mengetahui user name, email serta password EMIS TPQ X.

Hal ini terkadang sedikit menyulitkan pihak Administrator Kementerian Agama, dikarenakan kenyataan dilapangan banyak 
dari pihak yauasan/TPQ yang melupakan password EMIS-nya sendiri, sehingga akan menghambat seluruh proses pendataan dan pengolahan data yayasan/TPQ tersebut.

\section{Dampak penggunaan EMIS}

Berdasarkan wawancara yang kami lakukan, terdapat dampak positif dan negative yang diperoleh dari penggunaan aplikasi EMIS dalam proses pengolahan data, dampak tersebut yaitu:

\section{Dampak positif}

- Lebih mudah dalam penyimpanan data

Karena penyimpanan data menggunakan aplikasi, maka akan memudahkan penyimpanannya, tidak memerlukan ruangan dan juga tidak memakan banyak tempat.

- Lebih mudah dalam pencarian data

Pencarian data dalam aplikasi tentunya akan lebih mudah dan cepat, pengguna hanya perlu mengetik apa data apa saja yang diperlukan dipencarian, maka akan langsung keluar tanpa harus mencarinya satu-persatu.

- Lebih mudah dalam pengaksesan data Karena aplikasi berbasis online, jadi bisa diakses kapanpun dan dimanapun tanpa mengenal waktu dan tempat.

- Keamanan data lebih terjamin

Keamanan data tentunya tidak bisa diakses orang secara sembarangan, dengan menggunakan system log-in name dan password maka secara otomatis membatasi pengaksesan dari data tersebut.

Dampak negatif

- Perlunya biaya untuk akses internet

Tentunya diperlukan jaringan internet yang bagus untuk mengakses data nelalui EMIS, hal ini mengharuskan pengguna untuk mengeluarkan biaya untuk membeli kuota internet.

- Perlunya ketelitian yang ekstra dalam proses pengisian data Karena jika ada satu data saja yang kosong, maka system tidak akan menerima, sehingga diperlukan pengecekan ulang, bagian manakah yang kosong ataupun perlu diubah datanya. 


\section{Kesimpulan}

EMIS adalah sebuah sistem informasi yang di buat oleh Kementerian Agama. EMIS memiliki tujuan utama sebagai pengumpul, penyimpan, pengelola, analisis, dan penyebaran informasi yang digunakan untuk manajemen dan perencanaan pedidikan di bawah naungan Kementerian Pendidikan. Banyak keguinaan emis yang meliputi perencanaan alur informasi atar instansi memperbaiki kapasistas pengelolaan, penyimpanan, dan analisis data dalam menyediaikan informasi yang terpercaya. Dan tepat waktu dan masih banyaklagi keguanaan emisyang ada di dalam lembaga pendidikan tersebut. Selain madarasah EMIS juga mengelola data TPQ dan pondok pesantren yang telah di daftarkan.

BOP adalah bantuan operasional pendidikan yang di peruntukkan kepada pondok pesatren untuk pembiayaan operasinoal dan penunjang pendidikan yang ada di pondok pesatren. Dalam Kementerian Agama, seksi yang mengelola diniyah dan pondok pesantren adalah seksi pendidikan agama dan keagamaan islam.

Pencairan BOP bisa di lakasanakan melalui prosedur yang berdasarkaan SK Direktur Pendidikan Islam Kementerian Agama. Dalam pencairan dana BOP lemabaga pendidikan wajib melengkapi persyaratan yang jumlahnya ada 6 yang telah tercantum. Adapun lembaga pendidikian yang dapat mencairkan harus memiliki izin operasional yang di terbitkan oleh Kementerian Agama di setiap daerah dan harus melengkapi 10 persyaratan sebagai pengajuan izin operasional lembaga pendidikan.

Kendala yang dialami Kementrian Agama dalam menjalankan EMIS adalah kendala yang mendasar seperti kekurangan sumber daya manusia yang bisa mengoperasikan EMIS trsebut dan banyak lembaga yang tidak memiliki operator kusus yang menangani emis dadi tumpang tidih pekerjaan sehingga EMIS tidak terlaksana dengan baik. Jaringan dan kondisi server yang kurang lancer masih banyaknya lembaga pendidikan diniyah dan pondok pesantren yang berada di daerah terpencil menyebabkan jaringan internet yang belum merata sehingga menjadi permasalahan serius di dalam penggunaan EMIS tersebut. Kurang terperincianya EMIS khusus 
Kementerian Agama yang di maksud disini adalah kurang mengertinya administrator lembaga pendidikan yang kurang menjaga privasi dari lemabaga bpendidikanya sehingga lupa user nama dan paswornya sehingga menyebabkan tidak bisa di akses yang menyulitkan administrator kementerian agama untuk mereset dan menjadikannya semakin rumit..

Dalam penggunaan aplikasi EMIS pastilah mempunyai efek positif dan negatif. Dapak posistif yang di miliki oleh EMIS adalah lebih mudahnya penyimpanan data, mudahnya pencarian data, mudah dalam pengaksessan lembaga pendidikan, keamanan lebih terjamin. Adapun dampak negatif adalah perlunya biaya khusus untuk mengakses internet, perlunya ketelitian ektra dalam penginputan data ke dalam EMIS.

Emis adalah sebuah aplikasi sistem informasi manajmen pendidikan yang disediakan oleh kementrian agama guna memperbaiki sistem pendidikan dan mutu pendidikan yang ada di dalam pendidikan diniyah dan pondok pesatren. Maka dari itu perlu adanya perbaikan sistem yang ada di di pondok pondok yang ada saat ini. Masih banyaknya lembaga diniyah dan pondok pesatren yang belum memiliki administrator yang khusus menangani tentang administrasi adalah hal yang perlu di perbaiki. Selain kurikulum pendidikan dana pun juga penting dalam hal operasional lembaga pendidikan. Jadi dapat kita simpulkan perbaikan sumber daya manusi perlu di perbaiki guna mencetak administrator lembaga yang bisa menggunakan aplikasi tersebut agar bisa mencaikan dan yang ada untuk di alokasikan ke lembaga pendidikan sehingga dapat terserap secara optimal.

\section{References}

Aziz, Fuandi. 2014.“Pengambilan Kebijakan Berbasis Education Management Information System (EMIS)" Jurnal Pendidikan Islam.

Hamzah, Nina Lamatenggo. 2010. Teknologi Komunikasi dan Informasi Pembelajaran. 
$\begin{array}{llll}\text { Jakarta: } & \text { PT } & \text { Bumi } & \text { Aksara. }\end{array}$

https://ditpdpontren.kemenag.go.id/web/pengumuman/skbop-lpq/

https://id.wikipedia.org/wiki/Sistem_informasi_manajemen https://kbbi.kata.web.id/pengelolaan/ https://kemenagmajene.com/persyaratan-pendirian-tpa-tpq/

Miarso, Yusufhadi. 2004. Menyemai Benih Teknologi Pendidikan. Jakarta: Prenada Media Group

Petunjuk Teknis Bantuan Operasional Pondok Pesantren, Direktorat Pendidikan Diniyah Dan Pondok Pesantren Direktorat Jenderal Pendidikan Islam Kementerian Agama RI Tahun 2019.

Prawirosento, Suyadi. 2007. Filosofi Baru Tentang Manajemen Mutu Terpadu Abad 21.

Jakarta: Bumi Aksara.

Rasdiana, Sina dkk. 2020.“Penerapan Education Management Information System (EMIS) di Lembaga Pendidikan Keagamaan Dan Pondok Pesantren Pada Kantor Kementerian Agama Kota Makassar": Journal of Public Policy and Management.

Syarip, Dodi Irawan, dan Rosidin. 2003. System Manajemen Data dan Informasi Pendidikan di Lingkungan Jenderal Kelembagaan Agama Islam. Jakarta: Departemen Agama RI.

Umam, M. Choirul. 2019. Pengelolaan Elektronik Office di Universitas Yudharta Pasuruan: Skripsi. Surabaya: UINSA.

www.pengertianmenurutparaahli.net/pengertian-pengelolaanmenurut-para-ahli/

Zakia, Hanifa. "Sistem Informasi Manajemen Berbasis Database/DBMS Dalam Pengelolaan Data Siswa": Jurnal Manajemen. Universitas Negeri Padang. 